\title{
Aggregate characteristics and aggregate-associated soil organic carbon and carbohydrates of soils under contrasting tree land use
}

\author{
Bassey Udom ${ }^{1 *}$, Joshua Ogunwole ${ }^{2}$, Chima Wokocha ${ }^{1}$ \\ ${ }^{1}$ Department of Crop and Soil, University of Port Harcourt, P.M.B. 5323, Port Harcourt, Nigeria \\ ${ }^{2}$ Bowen University, Iwo, P.M.B. 284, Osun State, Nigeria
}

\section{ARTICLE INFO}

Keywords:

Clay content

Organic matter fraction

Plant cover

Soil structure

Water-stable aggregates

Article history

Submitted: 2021-07-22

Accepted: 2021-11-03

Available online: 2021-12-26

Published regularly: December 2021

* Corresponding Author
Email address:
ebassidy@yahoo.com

\section{ABSTRACT}

Protection of soil organic carbon and acid-hydrolyzable carbohydrates in aggregate-size fractions is important for appraising soil degradation and aggregation under land use types. Aggregate-associated soil organic carbon (SOC) and acid-hydrolyzable carbohydrates (R$\mathrm{CHO}$ ) in bulk soils and aggregate-size fractions of a sandy loam soil under Alchornea bush, Rubber, Oil palm and Teak plantations in southern Nigeria were studied. Results revealed significant differences in aggregate-associated SOC and $\mathrm{R}-\mathrm{CHO}$, bulk densities, total porosity, soil organic carbon stock and aggregate stability among the land use types. Greater SOC was stored in macro-aggregates $>0.25 \mathrm{~mm}$, while greater R-CHO was occluded in micro-aggregates $<0.25 \mathrm{~mm}(p<0.05)$. The highest mean weight diameter (MWD) was $1.01 \mathrm{~mm}$ in Alchornea soils and $0.92 \mathrm{~mm}$ in Oil palm plantation at $0-15 \mathrm{~cm}$ topsoil. Soil organic carbon stock in $0-15 \mathrm{~cm}$ topsoil was $77.7,81.8,92.2$, and $67.5 \mathrm{~kg} \mathrm{C} \mathrm{ha}^{-1}$ in Alchornea, Rubber, Oil palm, and Teak soils, respectively. Relationships showed a positive linear correlations between MWD and SOC $(r=0.793, p<0.05)$ and R-CHO $(r=0.789$. $p<$ $0.05)$. Alchornea bush and Oil palm plantation increased macro-aggregate formation and macro-pores $>5 \mu \mathrm{m}$, therefore they have greater potentials to boost protection of SOC in soil macro-aggregates.

\begin{abstract}
How to Cite: Udom, B., Ogunwole, J., \& Wokocha, C. (2021). Aggregate characteristics and aggregate-associated soil organic carbon and carbohydrates of soils under contrasting tree land use. Sains Tanah Journal of Soil Science and Agroclimatology, 18(2): 126-135. https://dx.doi.org/10.20961/stjssa.v18i2.53615
\end{abstract}

\section{INTRODUCTION}

Soil organic carbon storage in relation to aggregate hierarchy is driven by land use, organic and inorganic input, and organic matter stabilizing processes (Carrizo et al., 2015; Gentile et al., 2011). The location of soil organic carbon (SOC) in the hierarchical structure of soil aggregates determines the storage and transformation of SOC. Soil organic C accumulation and turnover have been used to assess the formation and stability of soil aggregates (Cates et al., 2016; Gupta \& Germida, 2015). Various authors have reported changes in aggregate-associated soil organic carbon and aggregation due to land-use systems (Cates et al., 2016; Udom \& Ogunwole, 2015).

Carbohydrates ( $\mathrm{R}-\mathrm{CHO}$ ) constitute a portion of the labile carbon pool in the soil, and as bonding agents for soil aggregates and energy sources for soil microorganisms (Maqubela et al., 2012). It represents a substantial portion of soil organic matter fraction, which confers stability to soil aggregates (Yousefi et al., 2008; Zhang et al., 2012). Various extractable forms of carbohydrates, including hot waterextractable and dilute acid-extractable carbohydrates are involved in the stabilization of soil aggregates. Studies revealed that carbohydrates are sensitive to land-use and management (de Souza et al., 2016) and that the labile carbon pool is sensitive to changes in land-use systems. The roles of polymeric carbohydrates on the aggregate stability of some soils have also been reported (Ratnayake et al., 2013). However, literature showed considerable controversy on the actual role of carbohydrate fractions on the aggregate stability of soils.

In the tropics, differences in opinion exist on the actual fraction of SOM that is responsible for soil aggregation. For example, Zhao et al. (2017) reported that organic matter 
fractions rather than the amount per se modified aggregate stability of the soil. While Annabi et al. (2011); Duchicela et al. (2013); Guo et al. (2019); Guo et al. (2018); Sun and Lu (2014) found a direct correlation between total SOM content and aggregate stability. In contrast, Carrizo et al. (2015) found no such positive correlations in similar studies, while Anaya and Huber-Sannwald (2015) reported different results for different types of organic matter fractions. Martins et al. (2012) found that the carbohydrate ( $\mathrm{R}-\mathrm{CHO}$ ) pool was not effective in the stability of soil aggregates, while Lykhman et al. (2020) found that $\mathrm{R}-\mathrm{CHO}$ was involved in aggregate stability in the presence of humified SOM pool.

Other studies observed that due to the temporary biological stability and rapid degradation of carbohydrates, their long-lasting role in soil aggregation differed in certain soil conditions, especially in the tropics (Albaladejo et al., 2013; Parwada \& Van Tol, 2017; Yılmaz et al., 2019). Carrizo et al. (2015) found that differences in plant cover, soil characteristics, types of extractable carbohydrates (cold or hot water or acid-hydrolyzed), influenced micro-and macroaggregate stability of soils. Whereas, Zubair et al. (2012) observed that carbohydrates extracted by hot water and dilute acid were suitable indicators for soil quality assessment, particularly in relation to soil aggregation. Debosz et al. (2002) found that hot-water extractable carbohydrates were higher in micro-aggregates than in macro-aggregates.

In relation to aggregate characteristics, Zhang et al. (2012) discussed soil aggregation and aggregating agents under longterm contrasting land use and found that smaller macroaggregates (WSA $0.25-2 \mathrm{~mm}$ ) had a larger accumulation of SOC and higher aggregate stability. Udom et al. (2016) reported that macro-aggregates $(>0.25 \mathrm{~mm}$ ) were effective in the protection of soil organic $C$ against losses. Other studies (Zhang et al., 2016), observed that $C$ derived from an invasive C4 grass Spartin was mainly distributed in macro-aggregates, while $C$ from a native $C$ plant Suaeda salsa was mostly found in micro-aggregates and free silt-sized fractions. Guan et al. (2015) found that additions of organic residues to the soil altered the distribution of SOC in aggregate-size fractions, especially in macro-aggregates $(>250 \mu \mathrm{m})$. Udom and Simon (2020) obtained high SOC and carbohydrate concentrations in dry-sieved macro-aggregates of forested than cultivated soils. Other studies such as Zhang et al. (2016) found that organic $C$ in micro-aggregates was less susceptible to change than in the macro-aggregates. Liu et al. (2014) and Nweke and Nnabude (2015) found that macro-aggregate stability was mainly due to the key roles of carbohydrate-associated-roots in wellstructured soils. In other studies, the encrustation of SOM within micro-aggregates was discussed as the fundamental pathway to SOC stock and protection from rapid degradation (Udom \& Ogunwole, 2015).

Literature suggests existing gaps in knowledge regarding the roles of organic carbon fractions and acid-hydrolyzable carbohydrates on soil aggregate structure under tree fallow farming systems. This will provide additional knowledge on the potential protection of soil organic $C$ and acidhydrolyzable carbohydrates in soil aggregates when these soils are converted to arable crop production. In this study, we quantified aggregate-size distribution and aggregateassociated SOC and carbohydrates of soils under Alchornea (Alchornea cordifolia), Rubber (Heavea brazillensis), Oil palm (Elaeis guineensis) and Teak (Tectonia grandis). The objectives of this study were to (i) quantify soil organic carbon and carbohydrate distributions within macro-and microaggregate size classes under these plant species; and (ii) evaluate soil organic carbon stock and the potentials of these tree plant cultures in protecting soil aggregates from disruption.

\section{MATERIALS AND METHODS}

\subsection{The study area and soil sampling}

The study was carried out on a 250 ha land in Port Harcourt ( $4^{\circ} 15^{\prime} \mathrm{N}$ and $7^{\circ} 30^{\prime} \mathrm{E}$ ), in Rivers State, Nigeria. The soil is classified as Arenic Acrisol (USDA, 2012). Mean annual rainfall in the area is more than $2000 \mathrm{~mm}$ in September and October. The mean annual maximum temperature is $30^{\circ} \mathrm{C}$. Four land use areas were identified viz: (1) 20-year Alchornea bush (Alchornea cordifolia), (2) 20-year rubber plantation (Heavea brazillensis), (3) 15-year oil palm plantation (Elaeis guineensis), and (4) 20-year forested teak plantation (Tectona grandis). Soil organic carbon, acid-extractable carbohydrates and lignin content of the plant residues from the different plant covers are presented in Table 1. Each land area was subdivided into 5 blocks (based on the physiographic position), giving a total of 20 plots of $50 \times 50 \mathrm{~m}$, for soil sample collections. Four replicates of disturbed and undisturbed soil samples were collected at 0-15 and 15-30 cm depths in each block. A total of 160 bulk and core soil samples were collected for laboratory analysis.

\subsection{Determination of particle size-distribution, bulk density, and total porosity}

Particle-size distribution was determined by the method of Gee and Or (2002). Bulk density was measured according to Grossman and Reinsch (2002) as:

Bulk density $=\frac{\mathrm{Md}}{\mathrm{Vb}}$

where Md is mass of oven-dried soil ( $\mathrm{g}$ ) and Vb volume of bulk soil $\mathrm{cm}^{3}$

Total porosity was determined by the method of Flint and Flint (2002) as:

$\%$ Total porosity $=\frac{\mathrm{Vw}}{\mathrm{Vb}} \times 100$

Where $\mathrm{Vw}$ is volume of water $\left(\mathrm{cm}^{3}\right)$, and $\mathrm{Vb}$ volume of bulk soil $\left(\mathrm{cm}^{3}\right)$

Macro-porosity (pore size $>5 \mu \mathrm{m}$ ) was calculated as:

$\%$ Macro-porosity $=\frac{\text { Volume of water drained at } 10 \mathrm{kPa}}{\text { Volume of bulk soil }} \times 100$

\%Micro-porosity =\%Total porosity - \%Macro-porosity

The field capacity moisture content was measured at -10 kPa. 
Table 1. Organic carbon, acid-extractable carbohydrate and lignin concentration in plant residues

\begin{tabular}{lccc}
\hline Plant residues & $\begin{array}{c}\text { Organic } \\
\text { carbon } \\
\left(\mathrm{g} \mathrm{kg}^{-1}\right)\end{array}$ & $\begin{array}{c}\text { Acid-extracted } \\
\text { carbohydrate } \\
\left(\mathrm{g} \mathrm{kg}^{-1}\right)\end{array}$ & $\begin{array}{c}\text { Lignin } \\
\left(\mathrm{g} \mathrm{kg}^{-1}\right)\end{array}$ \\
\hline $\begin{array}{l}\text { Alchornea } \\
\text { cordifolia }\end{array}$ & 559.2 & 367.3 & 107.5 \\
$\begin{array}{l}\text { Rubber } \\
\text { Oil palm }\end{array}$ & 167.9 & 93.7 & 116.2 \\
Teak & 339.3 & 230.5 & 214.8 \\
\hline
\end{tabular}

\subsection{Saturated hydraulic conductivity and water holding capacity}

Saturated hydraulic conductivity (Ksat) was measured by the constant head soil core method (Reynolds et al., 2002) and calculated as:

Ksat $=\frac{\mathrm{Q}}{(\mathrm{A} . \mathrm{T})} \times \frac{\mathrm{L}}{\Delta \mathrm{H}}$

where Ksat is the saturated hydraulic conductivity $\left(\mathrm{cm} \mathrm{h}^{-1}\right), \mathrm{Q}$ the volume of water $\left(\mathrm{cm}^{3}\right)$ that drained through a crosssectional area $A\left(\mathrm{~cm}^{2}\right), T$ is time $(S), L$ is length of core $(\mathrm{cm})$, and $\Delta \mathrm{H}$ the hydraulic head difference $(\mathrm{cm})$. Water holding capacity (WHC) at saturation was calculated as:

$W H C=\frac{(M w-M d)}{M d}$

where Mw is the mass of wet soil ( $g$ ) and Md the mass of oven-dried soil (g).

To obtain the macro-porosity the core samples were subjected to soil-water pressures of $-10 \mathrm{kPa}$ using the hanging water column method (Cassel \& Nielsen, 1986).

\subsection{Determination of organic carbon and organic carbon stock}

Total organic carbon was determined by the wet oxidation dichromate method with $\mathrm{H}_{2} \mathrm{SO}_{4}-\mathrm{K}_{2} \mathrm{Cr}_{2} \mathrm{O}_{7}$, followed by residual titration with $1 \mathrm{~N} \mathrm{HCl}$ (Nelson \& Sommers, 1996). Soil organic carbon for specific soil depth expressed as soil organic carbon stock (SOCS) was calculated and corrected to equivalent soil mass as described by (Marques et al., 2016) as:

SOCSd $=\sum(C \times \rho b \times D \times 0.1)$

where SOCSd is the SOC stock to specific soil depth $\mathrm{d}\left(\mathrm{kg} \mathrm{C} \mathrm{ha}^{-1}\right)$, $C$ is the organic $C$ content $\left(\mathrm{g} \mathrm{C} \mathrm{kg}^{-1}\right)$, pb the soil bulk density $\left(\mathrm{g} \mathrm{cm}^{-3}\right), \mathrm{D}$ the soil depth $(\mathrm{cm})$, and 0.1 is the correction factor.

\subsection{Aggregate fractionation and determination of carbohydrates and organic carbon}

The physical fractionation procedure of Cambardella and Elliott (1992) was used to obtain aggregate-size classes. The soil samples were dry-sieved through a nested sieve using a mechanical sieve shaker to obtain the following aggregatesize classes: $4.75-2,2-1,1-0.5,0.5-0.25$, and $0.25 \mathrm{~mm}$. Soil organic carbon (SOC) concentration in different aggregatesize classes was determined via the acid dichromate wetoxidation procedure (Nelson \& Sommers, 1996). The carbohydrate $(\mathrm{R}-\mathrm{CHO})$ concentration in dry-aggregate size classes was determined by the phenol-sulphuric acid hydrolytic extraction procedures, using $10 \mathrm{ml}$ of $0.25 \mathrm{M} \mathrm{H}_{2} \mathrm{SO}_{4}$.

\subsection{Determination of Aggregate Stability}

Water-stable aggregates (WSA) were measured by the wet-sieved (slaking pre-wet) process (Nimmo \& Perkins, 2002), using $50 \mathrm{~g}$ of the $4.75 \mathrm{~mm}$ dry aggregates. The mean weight diameter (MWD) of water-stable aggregates was calculated by the equation:

$M W D=\sum_{i-1}^{n} x i \times w i$

where $\mathrm{xi}$ is the mean diameter of each aggregate size fraction, and wi is the weight of aggregates in that size range.

\subsection{Statistical analysis}

Statistical analyses of the data were performed using the SAS software (SAS Institute, 2016). Analysis of variance was performed, followed by multiple comparisons. Means were separated according to the least significant difference of Fisher's protected test. A significant correlation coefficient was tested at $5 \%$ probability.

\section{RESULTS}

\subsection{Soil texture, bulk density, and porosity}

The soil is sandy loam at $0-15 \mathrm{~cm}$ and sandy clay loam at $15-30 \mathrm{~cm}$ depths. Sand content is between $812 \mathrm{~g} \mathrm{~kg}^{-1}$ and 817 $\mathrm{g} \mathrm{kg}^{-1}$ at $0-15 \mathrm{~cm}$ and $721 \mathrm{~g} \mathrm{~kg}^{-1}$ and $733 \mathrm{~g} \mathrm{~kg}^{-1}$ at $15-30 \mathrm{~cm}$ depth (Table 2). Clay content ranged between $68 \mathrm{~g} \mathrm{~kg}^{-1}$ at 0$15 \mathrm{~cm}$ and $162 \mathrm{~g} \mathrm{~kg}^{-1}$ at $15-30 \mathrm{~cm}$ depths. Significant statistical difference was obtained for bulk density in Alchornea soil ( $p<0.05)$. Bulk densities were 1.37, 1.45, 1.50, and $1.51 \mathrm{~g} \mathrm{~cm}$ ${ }^{3}$ for Alchornea, Rubber, Oil palm, and Teak, respectively, at 0-15 cm topsoil. In Table 2, total porosity was significantly higher $(p<0.05)$ at $0-15 \mathrm{~cm}$ for Alchornea soil at $48.3 \%$ in comparison to $45.3,43.4$, and $43 \%$ for Rubber, Oil palm, and Teak, respectively. At $15-30 \mathrm{~cm}$ depth, total porosity was also significantly higher $(p<0.05)$ at $47.9 \%$ for Alchornea compared to $41.1 \%$ for Rubber, $43 \%$ for Oil palm, and $40.4 \%$ for Teak. Macro-porosity (pores $<5 \mu \mathrm{m}$ ) was higher at $28.6 \%$ for Alchornea at $0-15 \mathrm{~cm}$ and $17.2 \%$ at $15-30 \mathrm{~cm}$ depths (Table 2). Alchornea plant significantly increased the macro-porosity by $22 \%, 133 \%$, and $151 \%$, compared to Rubber, Oil palm, and Teak, respectively.

\subsection{Hydraulic conductivity, water holding capacity and organic carbon stock}

In Table 3, saturated hydraulic conductivity (Ksat) was significantly influenced by land-uses $(p<0.05)$. The highest Ksat value of $48.4 \mathrm{~cm} \mathrm{~h}^{-1}$ was obtained for Alchornea at 0-15 $\mathrm{cm}$, followed by $26 \mathrm{~cm} \mathrm{~h}^{-1}$ for Rubber and 19.3 and 12.2 for Oil palm and Teak (Table 3 ). Permeability was rapid and moderately rapid for Alchornea and Rubber, while moderately slow for Oil palm and Teak soils. Ksat values of 19 3 and $12.2 \mathrm{~cm} \mathrm{~h}^{-1}$ were obtained at $0-15 \mathrm{~cm}$ for Oil palm and Teak soils. Water holding capacity (WHC) at $0-15 \mathrm{~cm}$ was significantly higher $(p<0.05)$ in Alchornea soils at $0.27 \mathrm{~g} \mathrm{~g}^{-1}$, whereas, Oil palm, Teak, and rubber showed a non-significant difference in WHC of the soil (Table 3). Soil organic carbon stock (SOCS) at 0-15 cm soil was $77.7 \mathrm{~kg} \mathrm{ha}^{-1}$ in Alchornea, $81.8 \mathrm{~kg} \mathrm{ha}^{-1}$ in Rubber, $92.2 \mathrm{~kg} \mathrm{ha}^{-1}$ in Oil palm and $67.5 \mathrm{~kg} \mathrm{ha}^{-1}$ in Teak soils. At $15-30 \mathrm{~cm}$ depth, the lowest value of $39.3 \mathrm{~kg} \mathrm{ha}^{-1}$ was obtained in Teak soil, compared to 76.2, 74.9, and 60.7 $\mathrm{kg} \mathrm{ha}^{-1}$ found in Alchornea, Rubber, and Oil palm soils, respectively. 
Table 2. Texture, bulk density and porosity of the soils under the various land use

\begin{tabular}{lcccccccc}
\hline Land use & $\begin{array}{c}\text { Sand } \\
\left(\mathrm{g} \mathrm{kg}^{-1}\right)\end{array}$ & $\begin{array}{c}\text { Silt } \\
\left(\mathrm{g} \mathrm{kg}^{-1}\right)\end{array}$ & $\begin{array}{c}\text { Clay } \\
\left(\mathrm{g} \mathrm{kg}^{-1}\right)\end{array}$ & Texture & $\begin{array}{c}\mathrm{BD} \\
\left(\mathrm{g} \mathrm{cm}^{-3}\right)\end{array}$ & $\begin{array}{c}\text { \%Macro } \\
\text { porosity }(>5 \mu \mathrm{m})\end{array}$ & $\begin{array}{c}\text { \%Micro } \\
\text { porosity }(<5 \mu \mathrm{m})\end{array}$ & $\begin{array}{c}\text { Total porosity } \\
(\%)\end{array}$ \\
\hline $\mathbf{0 - 1 5} \mathbf{~ c m}$ & & & & & & & & \\
Alchornea & $817 \mathrm{a}$ & $108 \mathrm{~b}$ & $75 \mathrm{a}$ & $\mathrm{SL}$ & $1.37 \mathrm{~b}$ & $28.6 \mathrm{a}$ & $19.7 \mathrm{~b}$ & $48.3 \mathrm{a}$ \\
Rubber & $815 \mathrm{a}$ & $110 \mathrm{~b}$ & $75 \mathrm{a}$ & $\mathrm{SL}$ & $1.45 \mathrm{a}$ & $23.5 \mathrm{a}$ & $21.8 \mathrm{~b}$ & $45.3 \mathrm{~b}$ \\
Oil palm & $812 \mathrm{a}$ & $120 \mathrm{a}$ & $68 \mathrm{a}$ & $\mathrm{SL}$ & $1.50 \mathrm{a}$ & $12.3 \mathrm{~b}$ & $31.1 \mathrm{a}$ & $43.4 \mathrm{~b}$ \\
Teak & $815 \mathrm{a}$ & $109 \mathrm{~b}$ & $76 \mathrm{a}$ & $\mathrm{SL}$ & $1.51 \mathrm{a}$ & $11.4 \mathrm{~b}$ & $31.6 \mathrm{a}$ & $43.0 \mathrm{~b}$ \\
$\mathbf{1 5 - 3 0 ~ c m}$ & & & & & & & & \\
Alchornea & $721 \mathrm{a}$ & $131 \mathrm{a}$ & $148 \mathrm{a}$ & $\mathrm{SCL}$ & $1.38 \mathrm{~b}$ & $17.2 \mathrm{a}$ & $30.7 \mathrm{a}$ & $47.9 \mathrm{a}$ \\
Rubber & $722 \mathrm{a}$ & $122 \mathrm{a}$ & $156 \mathrm{a}$ & $\mathrm{SCL}$ & $1.56 \mathrm{a}$ & $13.2 \mathrm{~b}$ & $27.9 \mathrm{a}$ & $41.1 \mathrm{~b}$ \\
Oil palm & $719 \mathrm{a}$ & $119 \mathrm{a}$ & $162 \mathrm{a}$ & $\mathrm{SCL}$ & $1.51 \mathrm{a}$ & $9.9 \mathrm{~b}$ & $33.1 \mathrm{a}$ & $43.0 \mathrm{~b}$ \\
Teak & $733 \mathrm{a}$ & $119 \mathrm{a}$ & $148 \mathrm{a}$ & $\mathrm{SCL}$ & $1.58 \mathrm{a}$ & $10.1 \mathrm{~b}$ & $30.3 \mathrm{a}$ & $40.4 \mathrm{~b}$ \\
\hline
\end{tabular}

Note: Means followed by the same letter in each column for each depth for each parameter are not significantly different at $\mathrm{p}<0.05$. BD- bulk density, SL- sandy loam, SCL- sandy clay loam.

Table 3. Hydraulic conductivity, water holding capacity, aggregate stability and organic carbon stock

\begin{tabular}{|c|c|c|c|c|}
\hline Land use & $\begin{array}{c}\text { Ksat } \\
\left(\mathrm{cm} \mathrm{hr}^{-1}\right)\end{array}$ & $\begin{array}{l}\text { WHC } \\
\left(\mathrm{g} \mathrm{g}^{-1}\right)\end{array}$ & $\begin{array}{c}\text { SOCS } \\
(\mathrm{kg} \mathrm{m-2})\end{array}$ & $\begin{array}{c}\text { Permeability } \\
\text { Class }\end{array}$ \\
\hline \multicolumn{5}{|l|}{$0-15 \mathrm{~cm}$} \\
\hline Alchornea & $48.42 a$ & $0.27 a$ & $77.7 b$ & Rapid \\
\hline Rubber & $25.98 b$ & $0.21 b$ & $81.8 b$ & $\begin{array}{c}\text { Moderately } \\
\text { rapid }\end{array}$ \\
\hline Oil palm & $19.30 \mathrm{~b}$ & $0.21 b$ & $92.2 \mathrm{a}$ & $\begin{array}{c}\text { Moderately } \\
\text { slow }\end{array}$ \\
\hline Teak & $12.2 \mathrm{c}$ & $0.21 b$ & $67.5 c$ & $\begin{array}{c}\text { Moderately } \\
\text { slow }\end{array}$ \\
\hline \multicolumn{5}{|l|}{$15-30 \mathrm{~cm}$} \\
\hline Alchornea & $20.23 a$ & $0.22 a$ & $76.2 \mathrm{a}$ & $\begin{array}{c}\text { Moderately } \\
\text { rapid }\end{array}$ \\
\hline Rubber & $18.75 a$ & $0.21 a$ & $74.9 a$ & $\begin{array}{c}\text { Moderately } \\
\text { slow }\end{array}$ \\
\hline Oil palm & $12.72 b$ & $0.21 a$ & $60.7 b$ & $\begin{array}{c}\text { Moderately } \\
\text { slow }\end{array}$ \\
\hline Teak & $12.54 b$ & $0.23 a$ & $39.3 c$ & $\begin{array}{c}\text { Moderately } \\
\text { slow }\end{array}$ \\
\hline
\end{tabular}

Note: Means followed by the same letter in each column for each depth for each parameter are not significantly different at $p<0.05$, Ksat- saturated hydraulic conductivity, WHCwater holding capacity, SOCS- soil organic carbon stock.

\subsection{Water stable aggregates and aggregate stability}

Water stable aggregates showed significant enhancement of large aggregates $W A_{2-1} \mathrm{~mm}$ in Alchornea soil at 0-15 cm (Table 4). Smaller macro-aggregates $W A_{0.5-0.25} \mathrm{~mm}$ was significantly higher $(p<0.05)$ in Teak and Rubber soils at 28 and $26 \%$. At $15-30 \mathrm{~cm}$ depth, smaller macro-aggregates

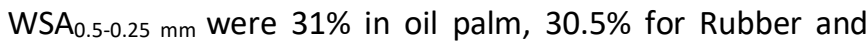
Teak, and $28 \%$ for Alchornea. In general, macro-aggregates $\geq 0.25 \mathrm{~mm}$ summed up to $75.5,71.5,70.0$, and $75 \%$ of the total soil mass in Alchornea, Rubber, Oil palm, and Teak, respectively, at $0-15 \mathrm{~cm}$, indicating general structural enhancement of the soils. Micro-aggregates $<0.25 \mathrm{~mm}$ were generally low in all the soils, with the lowest value of $18.5 \%$ obtained in Rubber soil at $0-15 \mathrm{~cm}$ topsoil, and $17 \%$ for Alchornea at $15-30 \mathrm{~cm}$ soil.
Aggregate stability measured by the mean weight diameter (MWD) of water-stable aggregates in Table 4 showed significant differences due to land use, with Alchornea soil having the highest in MWD of $1.01 \mathrm{~mm}$, compared to $0.89 \mathrm{~mm}$ found in Teak soil at $0-15 \mathrm{~cm}$ topsoil. The lowest MWD of $0.77 \mathrm{~mm}$ was obtained for Oil palm soil at $15-30 \mathrm{~cm}$ depth (Table 4). In general, the MWD values indicated the dominance of the less erodible aggregates.

\subsection{Aggregate-associated soil organic carbon}

Soil organic carbon (SOC) in bulk soils and aggregate-size classes showed significant differences due to land use (Figure 1). At $0-15 \mathrm{~cm}$, SOC concentration in the bulk soil was highest in Oil palm and Rubber (20.5 and $\left.19.8 \mathrm{~g} \mathrm{~kg}^{-1}\right)$. This was followed by $18.9 \mathrm{~g} \mathrm{~kg}^{-1}$ in Alchornea and the lowest value of $14.8 \mathrm{~g} \mathrm{~kg}^{-1}$ found in Teak. At $15-30 \mathrm{~cm}$ SOC concentrations in bulk soils were 18.4, 16.0, 13.4, and $8.3 \mathrm{~g} \mathrm{~kg}^{-1}$ for Alchornea, Rubber, Oil palm, and Teak, respectively. When compared to values obtained at $0-15 \mathrm{~cm}$, SOC decreased by $18.4 \%, 16.0,13.4$, and $78.3 \%$, respectively, in bulk soils for Alchornea, Rubber, Oil palm, and Teak. Results also revealed that $>65.8 \%$ of SOC was protected in macro-aggregates $>0.5 \mathrm{~mm}$ in Alchornea soils, compared to less than $45.1 \%$ in similar aggregate-size classes in Rubber, Oil palm and Teak soils (Figure 1). Alchornea and Oil palm soils stored $20.1 \mathrm{~g} \mathrm{~kg}^{-1}$ of $\mathrm{SOC}$ in $2.0-1.0 \mathrm{~mm}$ aggregate-size class and $22.6 \mathrm{~g} \mathrm{~kg}^{-1}$ in $0.5-0.25 \mathrm{~mm}$ aggregates at $15-30 \mathrm{~cm}$ depth. Generally, greater SOC was protected in macro-aggregates $>0.5 \mathrm{~mm}$ in Alchornea and Oil palm soils.

\subsection{Aggregate-associated carbohydrates}

Acid-hydrolyzable carbohydrates (R-CHO) were significantly $(p<0.05)$ higher in the bulk soil and macroaggregates $>0.5 \mathrm{~mm}$ in Achornea soils (Fig. 2). At 0-15 cm, R$\mathrm{CHO}$ concentration in bulk soil was in the order of Alchornea $>$ Rubber > Oil palm > Teak. The highest acid-hydrolyzable carbohydrates of $12.5 \mathrm{~g} \mathrm{~kg}^{-1}$ were stored in $4.75-2 \mathrm{~mm}$ aggregate-size class in Alchornea soil at $0-15 \mathrm{~cm}$ topsoil and $15-30 \mathrm{~cm}$ depth. For instance, aggregate-associated acidhydrolyzable carbohydrate concentrations in $4.75-2.0 \mathrm{~mm}$ aggregate-size class were $12.5 \mathrm{~g} \mathrm{C} \mathrm{kg}^{-1}$ for Alchornea, followed by $9.8 \mathrm{~g} \mathrm{C} \mathrm{kg}^{-1}$ in $0.5-0.25 \mathrm{~mm}$ for Oil palm soils at $15-30 \mathrm{~cm}$ depth. 

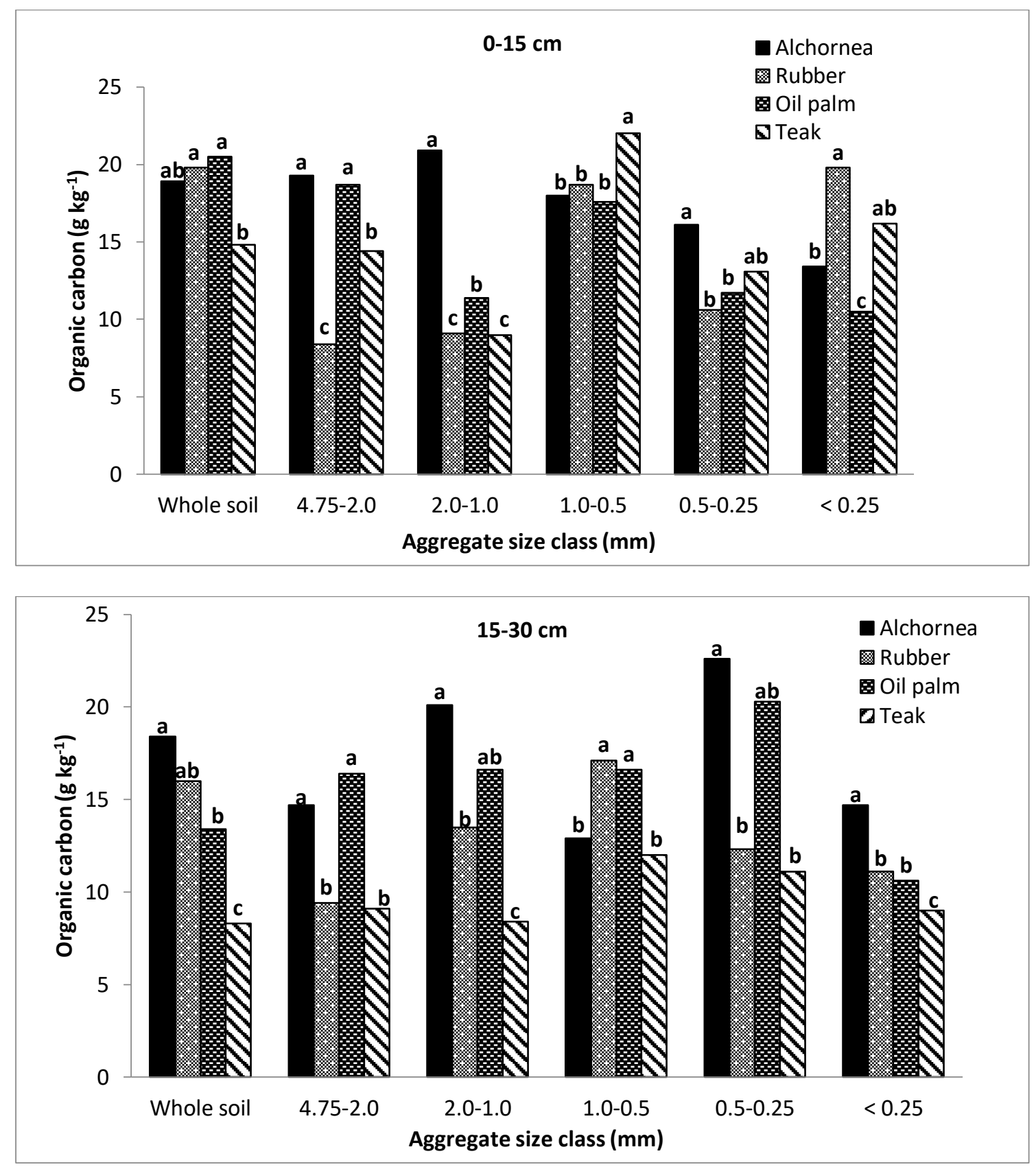

Figure 1. Distribution of soil organic carbon in whole soil and dry-aggregate sizes under different land use at 0-15 $\mathrm{cm}$ and $15-$ $30 \mathrm{~cm}$. Columns followed by the same letters for each aggregate size class for each depth are not significantly different at $p<0.0 .5$

Table 4. Water stable aggregates and aggregate stability of soil under different tree land use

\begin{tabular}{lcccccc}
\hline \multicolumn{1}{c}{ Land use } & $5-2 \mathrm{~mm}$ & $2-1 \mathrm{~mm}$ & $1-0.5 \mathrm{~mm}$ & $0.5-0.25 \mathrm{~mm}$ & $<0.25 \mathrm{~mm}$ & $\mathrm{MWD}(\mathrm{mm})$ \\
\hline $\mathbf{0 - 1 5} \mathbf{~ c m}$ & & & & & & \\
Alchornea & $12.0 \mathrm{a}$ & $17.0 \mathrm{a}$ & $27.0 \mathrm{~b}$ & $19.5 \mathrm{~b}$ & $24.5 \mathrm{~b}$ & $1.01 \mathrm{a}$ \\
Rubber & $9.5 \mathrm{a}$ & $13.0 \mathrm{~b}$ & $33.0 \mathrm{a}$ & $26.0 \mathrm{a}$ & $18.5 \mathrm{c}$ & $0.92 \mathrm{a}$ \\
Oil Palm & $11.0 \mathrm{a}$ & $12.0 \mathrm{~b}$ & $29.0 \mathrm{~b}$ & $20.0 \mathrm{~b}$ & $28.0 \mathrm{a}$ & $0.92 \mathrm{a}$ \\
Teak & $9.5 \mathrm{a}$ & $14.0 \mathrm{~b}$ & $23.5 \mathrm{c}$ & $28.0 \mathrm{a}$ & $25.0 \mathrm{~b}$ & $0.89 \mathrm{a}$ \\
$\mathbf{1 5 - 3 0 ~ c m}$ & & & & & & \\
Alchornea & $11.5 \mathrm{a}$ & $14.5 \mathrm{a}$ & $29.0 \mathrm{a}$ & $28.0 \mathrm{a}$ & $2.0 \mathrm{~b}$ & $0.99 \mathrm{a}$ \\
Rubber & $10.0 \mathrm{a}$ & $12.0 \mathrm{~b}$ & $28.0 \mathrm{a}$ & $30.5 \mathrm{a}$ & $2.5 \mathrm{~b}$ & $0.91 \mathrm{a}$ \\
Oil Palm & $5.0 \mathrm{~b}$ & $15.5 \mathrm{a}$ & $24.5 \mathrm{~b}$ & $31.0 \mathrm{a}$ & $24.0 \mathrm{a}$ & $0.77 \mathrm{~b}$ \\
Teak & $10.0 \mathrm{a}$ & $15.0 \mathrm{a}$ & $20.0 \mathrm{c}$ & $30.5 \mathrm{a}$ & $24.5 \mathrm{a}$ & $0.91 \mathrm{a}$ \\
\hline
\end{tabular}

Note: Means followed by the same letters for each aggregate size class for each depth are not significantly different at $p<0.05$, MWD- mean weight diameter. 
In general, aggregate-associated acid-hydrolyzable carbohydrates were in the order of 4.75-2.0 > 2.0-1.0 > 1-0.5 $\mathrm{mm}$ for Alchornea and Oil palm soils. The major contrast in aggregate-associated $\mathrm{R}-\mathrm{CHO}$ and $\mathrm{SOC}$ was that greater $\mathrm{R}-\mathrm{CHO}$ was stored in smaller aggregates $<0.25 \mathrm{~mm}$ in the subsoil, while greater SOC was specially protected in larger aggregates $4.75-2.0$ and $0.5-0.25 \mathrm{~mm}$ in $0-15 \mathrm{~cm}$ topsoil.

\subsection{Relationships amongst related soil properties}

Correlations among soil properties revealed a significant positive linear correlation between MWD and $\mathrm{R}-\mathrm{CHO}$ and SOC, accounting for 62.9 and $62.2 \%$ of the relationships, respectively (Table 5). A highly significant positive correlation was found between MWD and Ksat $(r=0.867, p<0.01)$, which explained $75.2 \%$ of the positive variation. A non-significant linear correlation between Ksat and $\mathrm{R}-\mathrm{CHO}(\mathrm{R}=0.466$, $\mathrm{p}>0.05)$, showed that SOC more than carbohydrates influenced the saturated hydraulic conductivity. Positive correlation between Ksat and SOC $(r=0.784, p<0.05)$, accounted for $61.5 \%$, while significant positive correlation between WHC and MWD accounted for $64.2 \%$ of the relationship ( $r=0.801, p<0.05)$, following an increase in Ksat and saturation water content of the soil (Table 5). Clay content showed significant positive linear correlation with $\mathrm{R}$ $\mathrm{CHO}(r=0.716, p<0.05)$, and a non-significant correlation with SOC $(r=0.459, p>0.05)$.

The equation, $\mathrm{R}-\mathrm{CHO}=0.816+1.524$ (clay), is suitable to predict the positive changes in carbohydrate content in soil depth with an increase or decrease in clay content. Microporosity showed a negative relationship with SOC $(r=-0.625$, $\mathrm{p}<0.05)$ and a positive linear relationship with $\mathrm{R}-\mathrm{CHO}(r=$ $0.717, p<0.05$ ), which further explained the positive role of clay content on acid-hydrolyzable $\mathrm{R}-\mathrm{CHO}$ in the soil. The model, macro-porosity $=1.648+2.051(\mathrm{SOC})$ is suitable to predict $67.1 \%$ of improvements in macro-porosity with increase in SOC content (Table 5). The correlation between macro-porosity and $\mathrm{R}-\mathrm{CHO}$ was not significant, accounting for only $25.7 \%$ of the relationship ( $r=0.507, p>0.05)$. Macroaggregates $>0.25 \mathrm{~mm}$ showed a highly positive correlation with SOC $(r=0.826, p<0.01)$, and a non-significant with $\mathrm{R}-\mathrm{CHO}$ $(r=0.531, p>0.05)$. The relationships between microaggregates $<0.25 \mathrm{~mm}$ and $\mathrm{SOC}$ and $\mathrm{R}-\mathrm{CHO}$ were significant $(r$ $=0.747, \quad p<0.05 ;$ and $r=0.709, \quad p<0.05$ ) respectively, accounted for $55.8 \%$ and $50.3 \%$, respectively in the formation of micro-aggregates in the soil.

\section{DISCUSSION}

Soil properties varied significantly in response to land use. The Alchornea reduced the soil bulk density (BD), increased saturated hydraulic conductivity (Ksat) and water holding capacity (WHC). The significant improvement of soil properties due to Alchornea plant could be attributed to the high production of quality organic residues, compared to the relatively low quality from Oil palm, Rubber and Teak. Quality and quantity of SOM from Alchornea bush have been reported to benefit soil physical properties through a reduction in bulk density and increase in the optimum moisture content of sandy loam soil (Udom \& Ehilegbu, 2018). The studies of Nweke and Nnabude (2015) also showed that quality rather than quantity of organic matter was responsible for the improvement of physical properties through possible rearrangement of the soil structures. The effect of vegetation on water-stable of aggregates (WSA) and the mean weight diameter (MWD) in this study could be used to explain the extent of soil agglomeration under the tree fallow systems.

Table 5. Relationships amongst some structural properties of the bulk soil and SOC, R-CHO, clay content $(N=20)$

\begin{tabular}{|c|c|c|c|}
\hline Regression equation & $\mathrm{R}^{2}$ & $\mathrm{R}$ & $P$ \\
\hline MWD $=-2.917+0.123(\mathrm{SOC})$ & 0.629 & 0.793 & $*$ \\
\hline MWD $=2.553+0.466(\mathrm{R}-\mathrm{CHO})$ & 0.622 & 0.789 & $*$ \\
\hline MWD $=2.096+0.111$ (Ksat) & 0.752 & 0.867 & $* *$ \\
\hline WHC $=1.492+2.014(\mathrm{MWD})$ & 0.642 & 0.801 & $*$ \\
\hline $\mathrm{K}_{\mathrm{sat}}=-10.84+2.903(\mathrm{R}-\mathrm{CHO})$ & 0.217 & 0.466 & NS \\
\hline $\mathrm{K}_{\mathrm{sat}}=0.862+2.486(\mathrm{SOC})$ & 0.615 & 0.784 & $*$ \\
\hline $\mathrm{R}-\mathrm{CHO}=0.816+1.524$ (clay) & 0.513 & 0.716 & $*$ \\
\hline SOC $=-2.461+1.601$ (clay) & 0.249 & 0.499 & NS \\
\hline Micro-porosity $=0.659+1.652$ (SOC) & 0.391 & -0.625 & $*$ \\
\hline Micro-porosity $=-3.019+1.702(\mathrm{R}-\mathrm{CHO})$ & 0.514 & 0.717 & $*$ \\
\hline Macro-porosity $=1.648+2.051(\mathrm{SOC})$ & 0.671 & 0.819 & $* *$ \\
\hline Macro-porosity $=0.216+2.111(\mathrm{R}-\mathrm{CHO})$ & 0.257 & 0.507 & NS \\
\hline Macro-aggregates $>0.25 \mathrm{~mm}=2.131+0.892(\mathrm{SOC})$ & 0.682 & 0.826 & $* *$ \\
\hline Macro-aggregates $>0.25 \mathrm{~mm}=-2.726+2.512(\mathrm{R}-\mathrm{CHO})$ & 0.281 & 0.531 & NS \\
\hline Micro-aggregates $<0.25 \mathrm{~mm}=0.792+1.601(\mathrm{R}-\mathrm{CHO})$ & 0.503 & 0.709 & $*$ \\
\hline Micro-aggregates $<0.25 \mathrm{~mm}=-1.812+0.151(\mathrm{SOC})$ & 0.558 & 0.747 & $*$ \\
\hline
\end{tabular}

Remarks: $\mathrm{R}^{2}$-Coefficient of determination, $\mathrm{R}$ - Coefficient of correlation, SOC - Soil organic carbon, MWD -Mean weight diameter, Ksat - Saturated Hydraulic conductivity, WHC- water holding capacity, R-CHO - Carbohydrate, *Significant at $\mathrm{p}<0.05, * *$ Significant at $\mathrm{p}<0.01$. 
Alchornea and Oil palm increased the macro-aggregate size classes 4.75-2.0 and 2.0-1.0 mm compared to Rubber and Teak, most probably supporting the quality of soil organic matter produced from Alchornea plants. This accession further confirmed the findings of Zhao et al. (2017) that the quality and quantity of SOM in a forest ecosystem were responsible for the production of macro-aggregates and stable structures in tropical sandy loam soil. The agglomeration of smaller aggregates into larger aggregates in Alchornea and Oil palm soils can be adduced to the SOM content in conjunction with the possibility of expansive activities of micro-organisms in the soil. Aggregate stability expressed by the MWD of water-stable aggregates reflected the proportion of larger aggregates produced in Alchornea soil, and consistent with studies of Devine et al. (2014); Liu et al. (2014), and Zhang et al. (2019) who found had an increase in production of macro-aggregates $>2.0 \mathrm{~mm}$ and large MWD due to organic residues added to the soil through the vegetation.

Soil organic $C$ stored in macro-aggregates $>0.25 \mathrm{~mm}$ was highest in Alchornea and Oil palm soils, which further confirms the works of Yu et al. (2012) and Abdelrhman et al. (2021) who found the encrustation of SOC in macroaggregates as a physical protective mechanism for soil aggregate against losses during disruption and erosion. The increase in acid-hydrolyzable carbohydrates in macroaggregates of Alchornea and Oil palm soils can also be used to suggest the improvement in soil aggregation under the Alchornea bush. However, other findings had differed in the conclusion that carbohydrates cannot always be considered as persistent structural stabilizers because of their rapid degradation by microbial activity (Udom \& Simon, 2020).
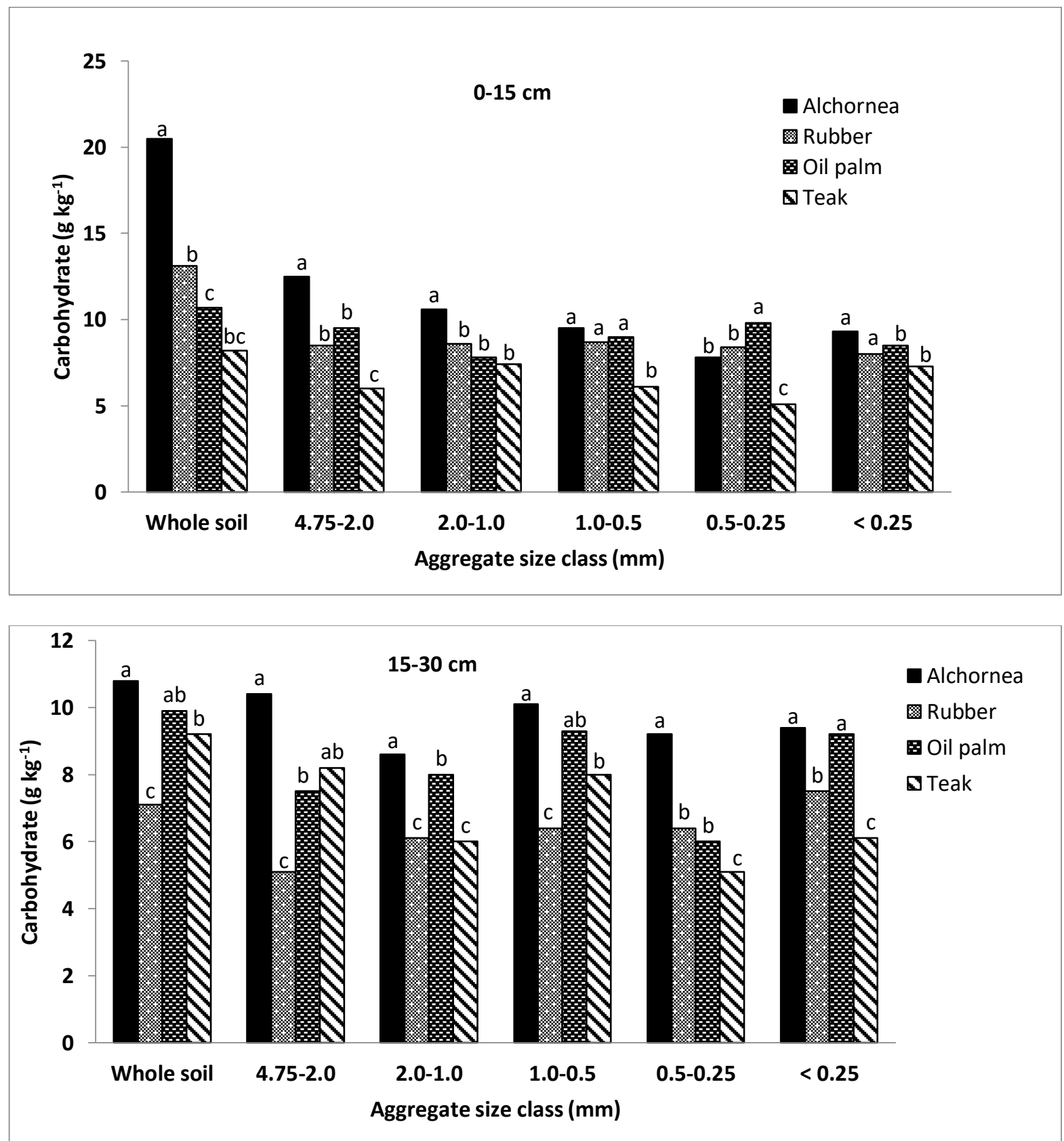

Figure 2. Distribution of carbohydrate $(\mathrm{R}-\mathrm{CHO})$ in whole soil and dry aggregate size class under different land use at $0-15 \mathrm{~cm}$ and $15-30 \mathrm{~cm}$. Columns followed by the same letters for each aggregate size class for each depth are not significantly different at $p<0.0 .5$. 
It is also possible to argue that the high carbohydrates and SOC found in Alchornea and Oil palm soils compared with the Rubber and Teak would have potentially rejuvenated the soil hydraulic and structural properties reported in Tables 1 and 2. This may further support the findings of Parwada and Van Tol (2017) that acid-hydrolyzable carbohydrate fractions alone did not improve macro-aggregate stability rather, the other components of organic matter such as the humified fractions of the SOM. A large amount of acid-hydrolyzable carbohydrates stored in micro-aggregates $<0.25 \mathrm{~mm}$ at $15-30$ $\mathrm{cm}$ depth was not surprising, because Gupta and Germida (2015) had earlier observed a high amount of acidhydrolyzable carbohydrates in the subsoil and related it to the activities of micro-organisms during micro-aggregate formation, rather than the amount of decomposable organic residues. This further explained the high amount of SOC in 0$15 \mathrm{~cm}$ topsoil may have been involved in the biological stabilization of carbohydrates and protected it from microbial degradation. This result partially confirmed the report of Zubair et al. (2012) that acid-hydrolyzable carbohydrates in macro-aggregates and sand-sized particles in this study may have been due to the microbial decomposition of organic residues from Alchornea. Further, it could be argued that the microbial-derived sugars in the plant residues may have accounted for a large proportion of carbohydrates stored in micro-aggregates, consistent with the studies of Xiao et al. (2017) and Udom and Benwari (2018) who found an increase in population and activities of bacteria in clay-sized fractions of tropical sandy loam soil. This way, it could be postulated that the preferential storage of acid-hydrolyzable carbohydrates in the clay-size micro-aggregates was most probably due to the increase of biological activities in claysized particles.

Relationships showed a positive linear correlation of MWD with SOC and acid-hydrolyzable carbohydrates ( $\mathrm{R}-\mathrm{CHO}$ ) confirming the positive roles of $\mathrm{SOC}$ and $\mathrm{R}-\mathrm{CHO}$ as aggregating agents when in association with soil aggregates (Zubair et al., 2012). Similarly, the positive correlation between MWD and Ksat confirmed the crucial role of SOC in relation to the structural stability of soil and to a large extent, the aeration capacity and water movement into and within the soil. The significant linear model between SOC and clay content is consistent with the earlier findings of Yu et al. (2012) who found that SOC was more stable in silt-clay fractions and within micro-aggregates. Also, the positive correlation between acid-hydrolyzable R-CHO and micro-porosity further confirmed that acid-hydrolyzable $\mathrm{R}-\mathrm{CHO}$ was more closely related to micro-porosity and contributed little to the percolation porosity as earlier reported by Zhang et al. (2016). The positive correlations of $\mathrm{SOC}$ and $\mathrm{R}-\mathrm{CHO}$ with microaggregates tended to further explain the involvement of SOC and $\mathrm{R}-\mathrm{CHO}$ in the stabilization of micro-aggregates, consistent with the report of Ratnayake et al. (2013). On the other hand, the non-significant correlation between $\mathrm{R}-\mathrm{CHO}$ and macroaggregates in tandem with the findings of Martins et al. (2012), who found that the carbohydrate pool did not promote macro-aggregate stability, rather the $\mathrm{SOC}$ and humic fractions of SOM that was responsible for the formation of macro-aggregates

\section{CONCLUSIONS}

Alchornea bush and Oil palm plantation reduced bulk density, increased total porosity and saturated hydraulic conductivity of the soils. They also increased the formation of macro-aggregates $>0.25 \mathrm{~mm}$. Soil organic $C$ was preferentially stored in larger aggregate size classes 4.75-2.0 mm and 2.0$1.0 \mathrm{~mm}$ in Alchornea and Oil palm soils. Acid-hydrolyzable carbohydrates and SOC showed a significant positive correlation with the MWD, while $\mathrm{R}-\mathrm{CHO}$ showed a positive relationship with micro-aggregates. A linear model showed that SOC controlled macro-porosity through an increase in saturated hydraulic conductivity $\left(\mathrm{K}_{\text {sat }}\right)$. Acid-hydrolysable carbohydrates had a non-significant effect in the formation of macro-aggregates $>0.25 \mathrm{~mm}$. The clay-size fraction most predicted the amount of carbohydrates under the tree fallow cultures. Alchornea and Oil palm fallow cultures increased macro-aggregate stability and boost the protection of SOC and $\mathrm{R}-\mathrm{CHO}$ within soil aggregates.

\section{Declaration of Competing Interest}

The authors declare no competing financial or personal interests that may appear and influence the work reported in this paper.

\section{References}

Abdelrhman, A. A., Gao, L., Li, S., Lu, J., Song, X., Zhang, M., Zheng, F., Wu, H., \& Wu, X. (2021). Long-Term Application of Organic Wastes Improves Soil Carbon and Structural Properties in Dryland Affected by Coal Mining Activity. Sustainability, 13(10), 5686. https://www.mdpi.com/2071-1050/13/10/5686

Albaladejo, J., Ortiz, R., Garcia-Franco, N., Navarro, A. R., Almagro, M., Pintado, J. G., \& Martínez-Mena, M. (2013). Land use and climate change impacts on soil organic carbon stocks in semi-arid Spain. Journal of Soils and Sediments, 13(2), 265-277. https://doi.org/10.1007/s11368-012-0617-7

Anaya, C. A., \& Huber-Sannwald, E. (2015). Long-term soil organic carbon and nitrogen dynamics after conversion of tropical forest to traditional sugarcane agriculture in East Mexico. Soil and Tillage Research, 147, 20-29. https://doi.org/10.1016/j.still.2014.11.003

Annabi, M., Le Bissonnais, Y., Le Villio-Poitrenaud, M., \& Houot, S. (2011). Improvement of soil aggregate stability by repeated applications of organic amendments to a cultivated silty loam soil. Agriculture, Ecosystems \& Environment, 144(1), 382389. https://doi.org/10.1016/j.agee.2011.07.005

Cambardella, C. A., \& Elliott, E. T. (1992). Particulate Soil Organic-Matter Changes across a Grassland Cultivation Sequence. Soil Science Society of America Journal, 56(3), 777-783. https://doi.org/10.2136/sssaj1992.036159950056000 30017x

Carrizo, M. E., Alesso, C. A., Cosentino, D., \& Imhoff, S. (2015). Aggregation agents and structural stability in soils with different texture and organic carbon contents. Scientia 
Agricola, 72, 75-82. https://doi.org/10.1590/01039016-2014-0026

Cassel, D. K., \& Nielsen, D. R. (1986). Field Capacity and Available Water Capacity. In Methods of Soil Analysis (pp. 901-926). https://doi.org/10.2136/sssabookser5.1.2ed.c36

Cates, A. M., Ruark, M. D., Hedtcke, J. L., \& Posner, J. L. (2016). Long-term tillage, rotation and perennialization effects on particulate and aggregate soil organic matter. Soil and Tillage Research, 155, 371-380. https://doi.org/10.1016/j.still.2015.09.008

de Souza, G. P., de Figueiredo, C. C., \& de Sousa, D. M. G. (2016). Relationships between labile soil organic carbon fractions under different soil management systems. Scientia Agricola, 73(6), 535-542. https://doi.org/10.1590/0103-9016-2015-0047

Debosz, K., Vognsen, L., \& Labouriau, R. (2002). Carbohydrates in hot water extracts of soil aggregates as influenced by long-term management. Communications in Soil Science and Plant Analysis, 33(3-4), 623-634. https://doi.org/10.1081/CSS120002768

Devine, S., Markewitz, D., Hendrix, P., \& Coleman, D. (2014). Soil Aggregates and Associated Organic Matter under Conventional Tillage, No-Tillage, and Forest Succession after Three Decades. PLOS ONE, 9(1), e84988. https://doi.org/10.1371/journal.pone.0084988

Duchicela, J., Sullivan, T. S., Bontti, E., \& Bever, J. D. (2013). Soil aggregate stability increase is strongly related to fungal community succession along an abandoned agricultural field chronosequence in the Bolivian Altiplano. Journal of Applied Ecology, 50(5), 12661273. https://doi.org/10.1111/1365-2664.12130

Flint, L. E., \& Flint, A. L. (2002). 2.3 Porosity. In Methods of Soil Analysis (pp. 241-254). https://doi.org/10.2136/sssabookser5.4.c11

Gee, G. W., \& Or, D. (2002). 2.4 Particle-Size Analysis. In Methods of Soil Analysis (pp. 255-293). https://doi.org/10.2136/sssabookser5.4.c12

Gentile, R., Vanlauwe, B., \& Six, J. (2011). Litter quality impacts short- but not long-term soil carbon dynamics in soil aggregate fractions. Ecological Applications, 21(3), 695-703. https://doi.org/10.1890/09-2325.1

Grossman, R. B., \& Reinsch, T. G. (2002). 2.1 Bulk Density and Linear Extensibility. In Methods of Soil Analysis (pp. 201-228). https://doi.org/10.2136/sssabookser5.4.c9

Guan, S., Dou, S., Chen, G., Wang, G., \& Zhuang, J. (2015). Isotopic characterization of sequestration and transformation of plant residue carbon in relation to soil aggregation dynamics. Applied Soil Ecology, 96, 1824. https://doi.org/10.1016/j.apsoil.2015.07.004

Guo, Z., Zhang, J., Fan, J., Yang, X., Yi, Y., Han, X., Wang, D., Zhu, P., \& Peng, X. (2019). Does animal manure application improve soil aggregation? Insights from nine long-term fertilization experiments. Science of The Total Environment, 660, 1029-1037. https://doi.org/10.1016/j.scitotenv.2019.01.051

Guo, Z. C., Zhang, Z. B., Zhou, H., Rahman, M. T., Wang, D. Z., Guo, X. S., Li, L. J., \& Peng, X. H. (2018). Long-term animal manure application promoted biological binding agents but not soil aggregation in a Vertisol. Soil and Tillage Research, 180, 232-237. https://doi.org/10.1016/j.still.2018.03.007

Gupta, V. V. S. R., \& Germida, J. J. (2015). Soil aggregation: Influence on microbial biomass and implications for biological processes. Soil Biology and Biochemistry, 80, A3-A9. https://doi.org/10.1016/j.soilbio.2014.09.002

Liu, M.-Y., Chang, Q.-R., Qi, Y.-B., Liu, J., \& Chen, T. (2014). Aggregation and soil organic carbon fractions under different land uses on the tableland of the Loess Plateau of China. CATENA, 115, 19-28. https://doi.org/10.1016/j.catena.2013.11.002

Lykhman, V., Klimenko, A., Dubinina, M., Naimi, O., \& Polienko, E. (2020). Influence of humic preparations on the content of carbohydrates in structural units and their water resistance. E3S Web Conf., 210, 04005. https://doi.org/10.1051/e3sconf/202021004005

Maqubela, M. P., Muchaonyerwa, P., \& Mnkeni, P. N. (2012). Inoculation effects of two South African cyanobacteria strains on aggregate stability of a silt loam soil. African Journal of Biotechnology, 11(47), 10726-10735. https://doi.org/10.5897/AJB11.2111

Marques, J. D. d. O., Luizão, F. J., Teixeira, W. G., Vitel, C. M., \& Marques, E. M. d. A. (2016). Soil organic carbon, carbon stock and their relationships to physical attributes under forest soils in central Amazonia. Revista árvore, 40, 197-208. https://doi.org/10.1590/0100-67622016000200002

Martins, M. d. R., Angers, D. A., \& Corá, J. E. (2012). Carbohydrate Composition and Water-Stable Aggregation of an Oxisol as Affected by Crop Sequence under No-Till. Soil Science Society of America Journal, 76(2),

475-484. https://doi.org/10.2136/sssaj2011.0110

Nelson, D. W., \& Sommers, L. E. (1996). Total Carbon, Organic Carbon, and Organic Matter. In Methods of Soil Analysis (pp. 961-1010). https://doi.org/10.2136/sssabookser5.3.c34

Nimmo, J. R., \& Perkins, K. S. (2002). 2.6 Aggregate Stability and Size Distribution. In Methods of Soil Analysis (pp. 317-328). https://doi.org/10.2136/sssabookser5.4.c14

Nweke, I., \& Nnabude, P. (2015). Aggregate stability of four soils as evaluated by different indices. Journal of Experimental Biology and Agricultural Sciences, 3(3), 246-252. https://doi.org/10.18006/2015.3(3).246.252

Parwada, C., \& Van Tol, J. (2017). Soil properties influencing erodibility of soils in the Ntabelanga area, Eastern Cape Province, South Africa. Acta Agriculturae Scandinavica, Section B - Soil \& Plant Science, 67(1), 67-76. https://doi.org/10.1080/09064710.2016.1220614

Ratnayake, R. R., Seneviratne, G., \& Kulasooriya, S. A. (2013). Effect of soil carbohydrates on nutrient availability in natural forests and cultivated lands in Sri Lanka. Eurasian Soil Science, 46(5), 579-586. https://doi.org/10.1134/S1064229313050177 
Reynolds, W. D., Elick, D. E., Youngs, E. G., Amoozegar, A., \& bootink, N. W. (2002). Saturated and field-unsaturated water flow parameters: laboratory methods. In J. $\mathrm{H}$. Dane \& C. G. Topp (Eds.), Methods of soil analysis, Part 4: Physical methods (pp. 802-817). Soil Science Society of America. https://doi.org/10.2136/sssabookser5.4

SAS Institute. (2016). SAS/STAT 9.1: User's guide (4th Edition ed., Vol. 1). SAS Institute.

Sun, F., \& Lu, S. (2014). Biochars improve aggregate stability, water retention, and pore-space properties of clayey soil. Journal of Plant Nutrition and Soil Science, 177(1), 26-33. https://doi.org/10.1002/jpln.201200639

Udom, B., \& Benwari, A. (2018). Bacteria to fungi ratio and organic carbon in no-till ultisols after applications of corn residues and poultry manure. International Journal of Plant \& Soil Science, 1-8. https://doi.org/10.9734/IJPSS/2018/40622

Udom, B. E., \& Ehilegbu, J. (2018). Critical moisture content, bulk density relationships and compaction of cultivated and uncultivated soils in the humid tropics. Asian Soil Research Journal, 1-9. https://doi.org/10.9734/asrj/2018/v1i2681

Udom, B. E., Nuga, B. O., \& Adesodun, J. K. (2016). Waterstable aggregates and aggregate-associated organic carbon and nitrogen after three annual applications of poultry manure and spent mushroom wastes. Applied Soil Ecology, 101, 5-10. https://doi.org/10.1016/j.apsoil.2016.01.007

Udom, B. E., \& Ogunwole, J. O. (2015). Soil organic carbon, nitrogen, and phosphorus distribution in stable aggregates of an Ultisol under contrasting land use and management history. Journal of Plant Nutrition and Soil Science, 178(3), 460-467. https://doi.org/10.1002/jpln.201400535

Udom, B. E., \& Simon, U. G. (2020). Effect of land-use on particulate organic carbon and carbohydrates distributions in dry- and wet-sieved stable aggregates in an ultisol. Niger. J. Soil Sci, 30(3), 1-8. http://journalservers.com/files/e7e0688b_1103\%20 \%20Udom\%20and\%20Simon

USDA. (2012). Soil Survey Manual (Revised). U. S. Department of Agriculture,

Xiao, S., Zhang, W., Ye, Y., Zhao, J., \& Wang, K. (2017). Soil aggregate mediates the impacts of land uses on organic carbon, total nitrogen, and microbial activity in a Karst ecosystem. Scientific Reports, 7(1), 41402. https://doi.org/10.1038/srep41402

Yılmaz, E., Çanakcı, M., Topakcı, M., Sönmez, S., Ağsaran, B., Alagöz, Z., Çıtak, S., \& Uras, D. S. (2019). Effect of vineyard pruning residue application on soil aggregate formation, aggregate stability and carbon content in different aggregate sizes. CATENA, 183, 104219. https://doi.org/10.1016/j.catena.2019.104219

Yousefi, M., Hajabbasi, M., \& Shariatmadari, H. (2008). Cropping system effects on carbohydrate content and water-stable aggregates in a calcareous soil of Central Iran. Soil and Tillage Research, 101(1), 57-61. https://doi.org/10.1016/j.still.2008.06.003

Yu, H., Ding, W., Luo, J., Geng, R., \& Cai, Z. (2012). Long-term application of organic manure and mineral fertilizers on aggregation and aggregate-associated carbon in a sandy loam soil. Soil and Tillage Research, 124, 170177. https://doi.org/10.1016/j.still.2012.06.011

Zhang, J., Wei, Y., Liu, J., Yuan, J., Liang, Y., Ren, J., \& Cai, H. (2019). Effects of maize straw and its biochar application on organic and humic carbon in waterstable aggregates of a Mollisol in Northeast China: A five-year field experiment. Soil and Tillage Research, 190, 1-9. https://doi.org/10.1016/j.still.2019.02.014

Zhang, S., Li, Q., Zhang, X., Wei, K., Chen, L., \& Liang, W. (2012). Effects of conservation tillage on soil aggregation and aggregate binding agents in black soil of Northeast China. Soil and Tillage Research, 124, 196-202. https://doi.org/10.1016/j.still.2012.06.007

Zhang, S., Wang, R., Yang, X., Sun, B., \& Li, Q. (2016). Soil aggregation and aggregating agents as affected by long term contrasting management of an Anthrosol. Scientific Reports, 6(1), 39107. https://doi.org/10.1038/srep39107

Zhao, J., Chen, S., Hu, R., \& Li, Y. (2017). Aggregate stability and size distribution of red soils under different land uses integrally regulated by soil organic matter, and iron and aluminum oxides. Soil and Tillage Research, 167 , 73-79. https://doi.org/10.1016/j.still.2016.11.007

Zubair, M., Anwar, F., Ashraf, M., Ashraf, A., \& Chatha, S. A. S. (2012). Effect of green and farmyard manure on carbohydrates dynamics of salt-affected soil. Journal of soil science and plant nutrition, 12, 497-510. https://doi.org/10.4067/S0718-95162012005000011 